\title{
HUBUNGAN PAPARAN DEBU DAN LAMA PAPARAN DENGAN GANGGUAN FAAL PARU PEKERJA OVERHAUL POWER PLANT
}

\author{
Kiky Aunillah Yolanda Ardam \\ Departemen Keselamatan dan Kesehatan Kerja \\ Fakultas Kesehatan Masyarakat Universitas Airlangga \\ E-mail: kikyolanda@gmail.com
}

\begin{abstract}
Dust exposure in the working environment is a potential factor to cause lung function disorders. Lung function disorders such as restriction, obstruction, and mixed-type which is indicated by decreasing \% FEV and \% FVC. Overhaul power plant workers have high risk dust exposure in the working environment as impact of the process overhaul power plant machine. Dust from overhaul work can entry to the respiratory tract of the workers through inhalation. The purpose was to analyze the relationship of total dust exposure and exposure time with lung function disorder among overhaul power plant workers in PT. PJB Unit Pelayanan Pemeliharaan Wilayah Timur. This research was an observational analytical study with cross sectional design. The sample size was 32 which were taken by simple random sampling technique. Relationship between dust exposure and exposure time with lung function disorders was analyzed statistically by using Chi Square Test $\left(\chi^{2}\right)$. The study found that only dust exposure was significantly relationship with lung function disorders $(p=0.006<\alpha=0.05)$ and the most prevalence of lung function disorders was mixed-type lung function impairment. It is recommended that the company provide Local Exhaust Ventilation (LEV) at the sources of contaminant (dust) and reduce the exposure time.
\end{abstract}

Keywords: dust exposure, exposure time, lung function disorders, overhaul

\begin{abstract}
ABSTRAK
Paparan debu di lingkungan kerja merupakan faktor potensial dalam menyebabkan gangguan faal paru. Gangguan faal paru dapat berupa restriksi, obstruksi dan kombinasi yang ditunjukkan dengan penurunan parameter $\% \mathrm{FEV}_{1}$ dan $\% \mathrm{FVC}$. Pekerja overhaul mesin pembangkit listrik memiliki kemungkinan besar terpapar debu di lingkungan kerja overhaul sebagai akibat dari proses pekerjaan pembersihan material mesin pembangkit listrik. Debu yang dihasilkan dari pekerjaan overhaul dapat masuk ke dalam saluran pernapasan pekerja secara inhalasi. Tujuan penelitian adalah menganalisis hubungan paparan debu total dan lama paparan dengan gangguan faal paru pekerja overhaul power plant di PT. PJB Unit Pelayanan Pemeliharaan Wilayah Timur. Penelitian ini merupakan penelitian observasional analitik dengan desain cross sectional. Sampel penelitian sebesar 32 pekerja diambil dengan teknik simple random sampling. Hubungan antara paparan debu dan lama paparan dengan gangguan faal paru dianalisis secara statistik dengan menggunakan uji Chi Square $\left(\chi^{2}\right)$. Hasil penelitian ditemukan bahwa hanya paparan debu yang terbukti secara signifikan terdapat hubungan dengan gangguan faal paru $(\mathrm{p}=0,006<\alpha=0,05)$ dengan prevalensi terbesar pekerja mengalami gangguan faal paru kombinasi. Saran dalam penelitian ini adalah perusahaan melakukan pemasangan Local Exhaust Ventilation (LEV) di titik sumber kontaminan berasal (debu) dan mengurangi lama paparan.
\end{abstract}

Kata kunci: paparan debu, lama paparan, gangguan faal paru, overhaul

\section{PENDAHULUAN}

Lingkungan kerja adalah salah satu faktor yang mampu menciptakan optimalisasi produktivitas kerja. Gangguan kesehatan dapat timbul karena adanya berbagai faktor yang ada di lingkungan kerja, seperti: faktor fisik, kimiawi, biologis, fisiologis, dan psikologis (Suma'mur, 2013).

Lingkungan kerja sangat mudah terpapar oleh faktor kimia seperti debu, uap dan gas. Debu adalah partikel padat yang dihasilkan oleh manusia atau alam dan merupakan hasil dari proses pemecahan suatu bahan produksi (Mukono, 2005).

Debu dalam kondisi tertentu merupakan agent kimia yang dapat menyebabkan pengurangan kenyamanan kerja, gangguan penglihatan, gangguan faal paru, bahkan dapat menimbulkan keracunan umum. Debu yang terinhalasi secara terus menerus dapat menyebabkan terjadinya kerusakan paru dan fibrosis. Debu dengan ukuran yang semakin kecil memiliki potensi yang semakin besar dalam menimbulkan gangguan faal paru pekerja karena 
debu dengan ukuran kurang dari $1 \mu$ dapat masuk dalam alveolus, sedangkan partikel debu $<0,1 \mu$ bergerak keluar masuk alveoli dan tidak mengendap dipermukaan alveoli (Suma'mur, 2013).

Data Internasional Labour Organization (ILO) tahun 2005 menyatakan bahwa terdapat 250 juta kasus penyakit akibat hubungan kerja yang mampu menyebabkan terjadinya 300.000 kematian di seluruh dunia dengan insiden rata-rata penyakit paru akibat kerja sebesar 1:1000 pekerja dalam setahun. Kasus Penyakit Akibat Kerja (PAK) tingkat dunia mencatat lebih dari 30\% PAK merupakan penyakit paru.

Kematian akibat penyakit paru kronik di New York mencapai angka lebih dari 3\% sebagai akibat dari lingkungan kerja yang mengandung agent pencemar yang mampu menimbulkan gangguan serius pada faal paru, sedangkan di Indonesia angka kesakitan dan penyebab kematian akibat gangguan saluran pernapasan menduduki peringkat 10 besar, termasuk bronchitis, asma dan ISPA bagian bawah (Perdana dkk, 2010).

Dinas Kesehatan Provinsi Jawa Tengah mengemukakan data terkait penyakit paru akibat kerja berdasarkan hasil penelitian tahun 2004 menyatakan bahwa $83,75 \%$ pekerja formal dan $95 \%$ pekerja informal mengalami gangguan faal paru (Yulaekah, 2007).

Pekerja industri di berbagai sektor memiliki potensi besar dalam terpapar debu di lingkungan kerja hingga menyebabkan terjadinya gangguan faal paru. Penelitian ini menggunakan populasi pada pekerja overhaul power plant di PT. PJB Unit Pelayanan Pemeliharaan Wilayah Timur karena pekerja overhaul tersebut dianggap memiliki peluang besar untuk terpapar (exposed) debu sebagai akibat dari pekerjaan yang dijalankan.

Identifikasi masalah berdasarkan hasil penelitian Risk Assassment oleh Kusuma (2013) menyatakan bahwa risiko tertinggi pada pekerjaan overhaul power plant adalah paparan debu, sehingga pekerja overhaul power plant berisiko tinggi mengalami gangguan pernapasan akibat paparan debu yang terhirup selama melakukan pekerjaan overhaul.

Hasil wawancara terhadap Supervisor bagian Keselamatan dan Kesehatan Kerja (K3) di PT. PJB Unit Pelayanan Pemeliharaan Wilayah Timur didapatkan pernyataan bahwa pekerja overhaul power plant sering melaporkan keluhan berupa sesak napas, batuk, dan rasa gatal di tenggorokan. Keluhan ini diduga karena udara di area kerja overhaul banyak mengandung debu akibat pekerjaan overhaul power plant.

Hasil wawancara tersebut didukung dengan hasil medical check up PT. PJB Unit Pelayanan Pemeliharaan Wilayah Timur Tahun 2013 yang menyatakan bahwa $13,72 \%$ pekerja mengalami gangguan faal paru, $64,71 \%$ pekerja memiliki faal paru normal, dan $21,57 \%$ pekerja tidak menjalani pemeriksaan. Data pendukung lain ditunjukkan pada data kunjungan Klinik PT. PJB Unit Pelayanan Pemeliharaan Wilayah Timur Bulan Januari - Maret 2015 yang menunjukkan bahwa Infeksi Saluran Pernapasan Akut (ISPA) merupakan penyakit terbanyak kedua setelah hipertensi dengan persentase kunjungan ISPA sebesar $21,25 \%$.

Pekerja overhaul power plant PT. PJB Unit Pelayanan Pemeliharaan Wilayah Timur dengan berbagai tahapan pekerjaan yang dijalankan memiliki kemungkinan besar dalam terpapar faktor kimia berupa debu. Berdasarkan uraian diatas penelitian ini bertujuan untuk menganalisis hubungan paparan debu dan lama paparan dengan gangguan faal paru pekerja overhaul power plant di PT. PJB Unit Pelayanan Pemeliharaan Wilayah Timur.

\section{METODE}

Penelitian ini merupakan jenis penelitian observasional karena dalam penelitian ini tidak memberikan perlakuan dan ditinjau dari cara analisis data penelitian ini termasuk dalam penelitian analitik dengan desain pendekatan cross sectional.

Penelitian dilaksanakan pada bulan April 2015 di PT. PJB Unit Pelayanan Pemeliharaan Wilayah Timur yang berlokasi di Kota Gresik, Jawa Timur, Indonesia. Populasi target dalam penelitian ini adalah seluruh pekerja overhaul power plant PT. PJB Unit Pelayanan Pemeliharaan Wilayah Timur sejumlah 129 pekerja dengan populasi studi sebesar 35 pekerja yang diperoleh berdasarkan kriteria inklusi.

Kriteria inklusi dalam penelitian adalah pekerja overhaul power plant dengan jenis kelamin laki-laki, memiliki masa kerja minimal 5 tahun, tidak memiliki riwayat penyakit pernapasan dan kardiovaskular, dan bersedia menjadi responden dalam penelitian ini.

Dari populasi studi sebesar 35 pekerja selanjutnya dilakukan pengambilan sampel penelitian dengan teknik pengambilan sampel secara Simple Random Sampling didapatkan sampel penelitian sebesar 32 pekerja. 
Penelitian ini terdiri dari 2 (dua) variabel, yaitu variabel dependen dan variabel independen. Variabel dependen dalam penelitian ini adalah gangguan faal paru sedangkan variabel independen dalam penelitian ini adalah paparan debu dan lama paparan.

Definisi operasional dalam penelitian ini, yaitu: (1) debu adalah jumlah seluruh paparan kadar debu yang terdapat di lingkungan kerja dalam semua ukuran debu yang disebut kadar debu total dengan satuan $\mathrm{mg} / \mathrm{m}^{3}$; (2) usia adalah ukuran usia dalam tahun yang dihitung mulai dari tahun kelahiran pekerja sampai tahun dilaksanakan penelitian dengan satuan tahun; (3) masa kerja adalah waktu bekerja yang terhitung sejak pertama kali mulai bekerja di overhaul power plant sampai tahun dilaksanakan penelitian dalam satuan tahun; (4) lama paparan adalah lama waktu paparan yang dialami pekerja dalam satu hari bekerja dengan satuan jam; (5) status merokok adalah pekerja yang menyatakan mempunyai kebiasaan merokok secara teratur. Status merokok meliputi perokok aktif, perokok pasif, dan telah berhenti merokok atau yang disebut mantan perokok; (6) derajat berat merokok dihitung dengan Indeks Brinkman (IB), yaitu jumlah ratarata batang rokok yang dihisap dikalikan dengan lama merokok dalam tahun. Derajat Berat Merokok dikategorikan dalam ringan, sedang, berat; (7) status gizi adalah hasil perhitungan Indeks Massa Tubuh (IMT) berdasarkan standar Asia menurut WHO (2000), yaitu: Under-weight, Normal, At Risk Obese, Obese I, dan Obese II; dan (8) status faal paru adalah Keadaan faal paru pekerja yang diukur dengan kapasitas ekspirasi paksa 1 detik $\left(\mathrm{FEV}_{1}\right)$ dan kapasitas vital paksa (FVC) yang dinyatakan dengan status normal dan gangguan.

Metode pengumpulan data dilakukan dengan mengumpulkan data primer dan sekunder. Data primer yang dikumpulkan meliputi kadar debu, antropometri pekerja, status faal paru, dan karakteristik pekerja. Data sekunder dalam penelitian ini meliputi profil perusahaan, jumlah pekerja, proses pekerjaan, kondisi fisik lingkungan kerja overhaul, dan data kesehatan pekerja overhaul PT. PJB Unit Pelayanan Pemeliharaan Wilayah Timur.

Teknik dan instrumen pengumpulan data dalam penelitian ini dilakukan melalui pengukuran kadar debu di lingkungan kerja overhaul dengan alat ukur Low Volume Dust Sampler (LVDS), pengukuran antropometri dengan alat ukur microtoise dan timbangan badan merek SECA, pemeriksaan faal paru pekerja dengan alat ukur Spirometer merek Minota yang lengkap dengan mouth piece dan penjepit hidung dan pengumpulan data karakteristik pekerja dengan kuisioner.

Teknik analisis data dalam penelitian ini menggunakan analisis univariat dan bivariat. Analisis univariat digunakan untuk menganalisis data secara deskriptif dengan menggunakan tabel distribusi frekuensi, nilai rata-rata, standar deviasi, nilai jangkauan, dan nilai minimal maksimal. Analisis bivariat digunakan untuk menganalisis adanya hubungan dan kuat hubungan antara paparan debu dan lama paparan dengan gangguan faal paru. Analisis bivariat dalam penelitian ini menggunakan uji statistika dengan teknik analisis Chi Square Test $\left(\chi^{2}\right)$.

\section{HASIL}

PT. PJB Unit Pelayanan Pemeliharaan Wilayah Timur (PT. PJB UPHT) adalah perusahaan yang bergerak di bidang pelayanan pemeliharaan, perawatan, perbaikan mesin pembangkit. Pekerjaan overhaul power plant adalah salah satu pekerjaan yang bertujuan untuk merekondisi mesin pembangkit. PT. PJB Unit Pelayanan Pemeliharaan Wilayah Timur memiliki salah satu program kerja yang bertujuan untuk pembersihan dan pemeliharaan mesin pembangkit yang disebut pekerjaan overhaul power plant.

Pekerjaan overhaul power plant adalah salah satu pekerjaan yang bertujuan untuk merekondisi mesin pembangkit atau menjadikan mesin pembangkit kembali pada kondisi standar setelah lama beroperasi. Pekerja overhaul power plant terdiri dari pekerja bagian control \& instrument, mekanik, listrik, dan K3 \& 5S.

\section{Karakteristik Responden}

Distribusi karakteristik responden pekerja overhaul power plant tersaji pada Tabel 1.

Karakteristik responden pekerja overhaul power plant dalam penelitian ini meliputi usia, masa kerja, status merokok, dan status gizi pekerja. Distribusi responden berdasarkan usia pekerja overhaul power plant diketahui mayoritas pekerja overhaul berada pada kelompok usia 21-30 tahun (34,37\%) sedangkan minoritas pekerja berada pada kelompok usia $\leq 20$ tahun $(6,25 \%)$ dengan usia rata-rata pekerja adalah $34,13 \pm 0,931$ tahun. 
Tabel 1. Distribusi Responden Pekerja Overhaul Power Plant PT. PJB UPHT Tahun 2015

\begin{tabular}{lrr}
\hline \multicolumn{1}{c}{ Karakteristik Pekerja } & n & \% \\
\hline Usia & & \\
$\leq 20$ tahun & 2 & 6,25 \\
$21-30$ tahun & 11 & 34,37 \\
$31-40$ tahun & 10 & 31,25 \\
$>40$ tahun & 9 & 28,13 \\
\hline Masa Kerja & & \\
5-10 tahun & 28 & 87,50 \\
$>10$ tahun & 4 & 12,50 \\
\hline Lama Paparan & & \\
$<8$ jam & 8 & 25,00 \\
8 jam & 14 & 43,75 \\
$>8$ jam & 10 & 31,25 \\
\hline Status Merokok & & \\
Perokok Aktif & 23 & 71,87 \\
Perokok Pasif & 6 & 18,76 \\
Mantan Perokok & 3 & 9,37 \\
\hline Status Gizi & & \\
Underweight & 6 & 18,76 \\
Normal & 12 & 37,50 \\
At Risk Obese & 7 & 21,87 \\
Obese I & 7 & 21,87 \\
\hline Status Faal Paru & & \\
Normal & 4 & 12,50 \\
Gangguan & 28 & 87,50 \\
\hline Total & 32 & 100,00 \\
\hline Derajat Berat Merokok & & \\
Ringan & 18 & 69,23 \\
Sedang & 7 & 26,92 \\
Berat & 1 & 3,85 \\
\hline Total & 26 & 100,00 \\
\hline$\quad$ &
\end{tabular}

Masa kerja maksimal pekerja overhaul power plant adalah 20 tahun, sedangkan masa kerja minimal adalah 5 tahun. Mayoritas pekerja memiliki masa kerja $\leq 10$ tahun $(87,50 \%)$ dengan median masa kerja adalah 5 tahun.

Lama paparan yang dialami pekerja rata-rata adalah 7,95jam sehari. Lama paparan dihitung dari hasil pengurangan antara total waktu kerja dalam sehari dengan waktu istirahat pekerja. Pekerja overhaul power plant sebagian besar mengalami lama paparan 8 jam sehari $(43,75 \%)$, namun terdapat pekerja dengan lama paparan lebih dari 8 jam sehari (31,25\%).

Pekerja overhaul power plant sebagian besar berstatus pekok aktif $(71,87 \%)$ sedangkan hanya sebagian kecil yang berstatus perokok pasif $18,76 \%$ ) dan mantan perokok $(9,37 \%)$. Perokok aktif adalah pekerja yang menyatakan memiliki kebiasaan teratur merokok dan menghisap rokok secara langsung, perokok pasif adalah pekerja bukan perokok namun secara tidak langsung turut menghisap asap rokok, sedangkan mantan perokok adalah pekerja yang menyatakan diri telah berhenti merokok.

Pekerja dengan status perokok aktif dan mantan perokok sejumlah 26 orang selanjutnya diidentifikasi derajat berat merokok yang dialami dengan menggunakan Indeks Brinkman (IB). Mayoritas pekerja overhaul power plant berada pada derajat berat merokok kategori ringan sejumlah 18 pekerja dengan persentase $(69,23 \%)$ berdasarkan penilaian dengan Indeks Brinkman (IB). Pekerja overhaul power plant dalam kategori berat merokok tingkat ringan adalah pekerja dengan hasil nilai Indeks Brinkman (IB) kurang dari 200.

Status gizi pekerja overhaul power plant diketahui bahwa status gizi yang dimiliki oleh pekerja terdiri dari kategori status gizi dibawah normal (underweight), normal, berisiko obesitas (at risk obese), obesitas tingkat I, dan tidak ada seorang pun pekerja yang memiliki status gizi obesitas tingkat II. Pekerja overhaul power plant mayoritas memiliki status gizi normal $(37,50 \%)$ berdasarkan penilaian Indeks Massa Tubuh (IMT) yang berarti berat badan berdasarkan tinggi badan pekerja tidak termasuk dalam kategori normal.

Status faal paru pekerja overhaul power plant dikategorikan menjadi normal dan gangguan. Parameter yang digunakan dalam menentukan gangguan faal paru adalah nilai $\mathrm{FEV}_{1}$ (Force Expiratory Volume in one second) dan FVC (Forced Vital Capacity). Gangguan faal paru terdiri dari gangguan restriksi, obstruksi, dan kombinasi.

Gangguan restriksi adalah terjadinya hambatan dari pengembangan paru, sedangkan gangguan obstruksi adalah terjadinya hambatan pada aliran udara. Gangguan kombinasi adalah terjadinya gangguan faal paru gabungan antara restriksi dan obstruksi.

Gangguan faal paru yang dialami pekerja terdiri dari gangguan restriksi dan gangguan kombinasi. Faal paru pekerja overhaul power plant PT. PJB Unit Pelayanan Pemeliharaan Wilayah Timur merupakan keadaan fungsi fisiologis paru pekerja yang dilihat berdasarkan parameter kapasitas ekspirasi paksa dalam 1 detik $\left(\mathrm{FEV}_{1}\right)$ dan kapasitas vital paksa (FVC). Pengukuran faal paru pekerja overhaul power plant PT. PJB UPHT diketahui berdasarkan hasil pemeriksaan faal paru yang dilakukan kepada 32 pekerja sebagai responden.

Status faal paru pekerja ditemukan 4 pekerja berstatus faal paru normal dengan persentase sebesar 
$12,50 \%$, sedangkan 28 pekerja mengalami gangguan faal paru $(87,50 \%)$. Gangguan faal paru yang dialami oleh 28 pekerja overhaul selanjutnya diidentifikasi tipe gangguan faal paru yang dialami pekerja.

Gangguan faal paru terbanyak yang diderita pekerja adalah gangguan faal paru tipe kombinasi $(82,14 \%)$ dan sebesar $17,86 \%$ pekerja mengalami gangguan restriksi, sedangkan tidak seorang pun pekerja yang mengalami gangguan obstruksi.

\section{Identifikasi Kadar Debu di Lingkungan Overhaul Power Plant}

Debu di lingkungan kerja overhaul power plant diukur di 2 titik, yaitu Titik pertama berlokasi di Lantai 2 Sistim Turbin Condensate sedangkan Titik 2 berlokasi di Lantai 2 Sistim Turbin. Pengukuran debu di masing-masing titik dilakukan selama 30 menit dengan menggunakan alat ukur LVDS.

Debu yang terukur di area pekerjaan overhaul power plant merupakan kadar debu total yang dihasilkan dari proses pembersihan mesin condensate sebagai salah satu mesin pembangkit listrik. Paparan kadar debu total di lingkungan pekerjaan overhaul power plant yang diukur di Titik 1 dan Titik 2 diketahui bahwa kadar debu di lingkungan kerja masih berada di bawah Nilai Ambang Batas. Berdasarkan peraturan yang berlaku yaitu Permenakertrans Nomor 13 Tahun 2011 tentang Nilai Ambang Batas Faktor Fisika dan Kimia di Tempat Kerja.

Paparan kadar debu terukur di titik 1 (Lantai 1 Sistim Turbin Condensate) adalah $5,35 \mathrm{mg} / \mathrm{m}^{3}$ sedangkan paparan kadar debu di titik 2 (Lantai 1 Sistim Turbin) sebesar1,34 mg/m 3 , sehingga kadar debu di lingkungan pekerjaan overhaul power plant masih berada dalam batas aman berdasarkan Peraturan Menteri Tenaga Kerja dan Transmigrasi dalam PER. 13/MEN/X/2011 tentang Nilai Ambang Batas (NAB) Faktor Fisika dan Kimia di Tempat Kerja yang menyatakan bahwa NAB untuk kadar debu total di lingkungan kerja sebesar $10 \mathrm{mg} / \mathrm{m}^{3}$ yang dapat diterima oleh pekerja tanpa mengakibatkan penyakit akibat kerja atau gangguan kesehatan selama melakukan pekerjaan untuk waktu yang tidak melebihi 8 jam sehari atau 40 jam seminggu.

Pekerja yang terpapar debu dengan kadar 1,34 $\mathrm{mg} / \mathrm{m}^{3}$ jumlahnya lebih sedikit dibandingkan pekerja yang terpapar kadar debu $5,35 \mathrm{mg} / \mathrm{m}^{3}$. Pekerja di bidang mekanik, control \& instrument, dan K3 \& 5S sejumlah 22 orang dengan persentase $68,75 \%$ berada pada lingkungan kerja dengan paparan debu $5,35 \mathrm{mg} / \mathrm{m}^{3}$, sedangkan pekerja dibidang listrik dan K3 \& 5S lainnya sejumlah 10 orang dengan persentase sebesar $31,25 \%$ berada pada lingkungan kerja dengan paparan debu1,34 mg/m $\mathrm{m}^{3}$.

Mayoritas pekerja overhaul power plant berada pada lingkungan kerja dengan paparan debu tertinggi yaitu $5,35 \mathrm{mg} / \mathrm{m}^{3}$ yang dialami oleh pekerja overhaul di bidang mekanik, control\& instrument, danK3 \& 5S. Identifikasi hasil paparan debu total di lingkungan pekerjaan overhaul power plant PT. PJB Unit Pelayanan Pemeliharaan Wilayah Timur tersaji dalam Tabel 2.

\section{Hubungan Karakteristik Pekerja dengan Gangguan Faal Paru}

Hubungan karakteristik pekerja dengan gangguan faal paru pekerja overhaul power plant dianalis dengan menggunakan crosstabs dan secara statustik menggunakan Chi Square Test.

Berikut hubungan karakteristik pekerja dengan gangguan faal paru pekerja overhaul power plant tersaji pada Tabel 3 sebagai berikut:

Tabel 2. Hasil Pengukuran Paparan Debu di Lingkungan Kerja Overhaul Power Plant PT PJB Unit Pelayanan Pemeliharaan Wilayah Timur Tahun 2015

\begin{tabular}{lclcc}
\hline \multicolumn{1}{c}{ Area Kerja } & $\begin{array}{c}\text { Kadar Debu } \\
\left(\mathbf{m g} / \mathbf{m}^{\mathbf{3}}\right)\end{array}$ & \multicolumn{1}{c}{ Bagian Kerja } & Frekuensi Pekerja & $\begin{array}{c}\text { Persentase } \\
(\mathbf{\%})\end{array}$ \\
\cline { 3 - 5 } Titik 1 di Lantai 2 & 5,35 & Mekanik & 17 & 68,75 \\
& & Control \& Instrumen & 4 & \\
\hline Titik 2 di Lantai 1 & & K3 dan 5S & 1 & 31,25 \\
& \multirow{2}{*}{1,34} & Listrik & 8 & $\mathbf{1 0 0 , 0 0}$ \\
\hline Total & & K3 dan 5S & $\mathbf{3 2}$ & $\mathbf{1 0 0}$ \\
\hline
\end{tabular}


Tabel 3. Hubungan Karakteristik Pekerja dengan Gangguan Faal Paru Pekerja Overhaul Power Plant PT. PJB Unit Pelayanan Pemeliharaan Wilayah Timur Tahun 2015

\begin{tabular}{|c|c|c|c|c|c|c|}
\hline \multirow{3}{*}{$\begin{array}{c}\text { Karakteristik } \\
\text { Pekerja }\end{array}$} & \multicolumn{4}{|c|}{ Status Faal Paru } & \multirow{2}{*}{\multicolumn{2}{|c|}{ Total }} \\
\hline & \multicolumn{2}{|c|}{ Gangguan } & \multicolumn{2}{|c|}{ Normal } & & \\
\hline & $\mathbf{n}$ & $\%$ & n & $\%$ & $\mathrm{n}$ & $\%$ \\
\hline \multicolumn{7}{|l|}{ Usia } \\
\hline$\leq 20$ tahun & 2 & 100 & 0 & 0 & 2 & 100 \\
\hline $31-30$ tahun & 11 & 100 & 0 & 0 & 11 & 100 \\
\hline $31-40$ tahun & 8 & 80,00 & 2 & 20,00 & 10 & 100 \\
\hline$>40$ tahun & 7 & 77,78 & 2 & 22,22 & 9 & 100 \\
\hline \multicolumn{7}{|l|}{ Masa Kerja } \\
\hline 5-10 tahun & 25 & 89,29 & 3 & 10,71 & 28 & 100 \\
\hline$>10$ tahun & 3 & 75,00 & 1 & 25,00 & 4 & 100 \\
\hline \multicolumn{7}{|l|}{ Status } \\
\hline \multicolumn{7}{|l|}{ Merokok } \\
\hline Perokok Aktif & 19 & 82,61 & 4 & 17,39 & 23 & 100 \\
\hline Perokok Pasif & 6 & 100 & 0 & 0 & 6 & 100 \\
\hline $\begin{array}{l}\text { Mantan } \\
\text { Perokok }\end{array}$ & 3 & 100 & 0 & 0 & 3 & 100 \\
\hline \multicolumn{7}{|l|}{ Status Gizi } \\
\hline Underweight & 6 & 100 & 0 & 0 & 6 & 100 \\
\hline Normal & 10 & 83,33 & 2 & 16,67 & 12 & 100 \\
\hline At Risk Obese & 5 & 71,42 & 2 & 28,58 & 7 & 100 \\
\hline Obese I & 7 & 100 & 0 & 0 & 7 & 100 \\
\hline
\end{tabular}

Hubungan usia pekerja dengan gangguan faal paru pekerja overhaul power plant diketahui bahwa pekerja dengan kelompok usia 21-30 tahun merupakan kelompok pekerja yang lebih banyak mengalami gangguan faal paru, namun pekerja dengan kelompok usia termuda $\leq 20$ tahun justru mengalami gangguan faal paru paling sedikit dibandingkan kelompok usia lainnya. Hasil analisis menggunakan statistik Chi Square Test menunjukkan $\chi^{2}$ hitung $=3,20$ dengan nilai $\mathrm{p}=0,40>\alpha=0,05$, maka berdasarkan perbandingan nilai $\mathrm{p}$ dan $\alpha$ tersebut jelas terlihat bahwa nilai $\mathrm{p}$ lebih besar dibandingkan nilai $\alpha$ yang artinya adalah tidak ada hubungan usia pekerja dengan kejadian gangguan faal paru pekerja overhaul power plant PT. PJB Unit Pelayanan Pemeliharaan Wilayah Timur.

Hubungan masa kerja dengan gangguan faal paru pekerja overhaul power plant diketahui bahwa pekerja dengan masa kerja 5-10 tahun maupun $>10$ tahun sama-sama memiliki peluang untuk mengalami gangguan faal paru, namun Tabel 3 menunjukkan bahwa pekerja dengan masa kerja 5-10 tahun lebih banyak yang mengalami gangguan faal paru. Hasil analisis data dengan menggunakan statistik $C h i$ Square Test menunjukkan $\mathrm{p}=0,43>\alpha=0,05$ maka berdasarkan perbandingan nilai $\mathrm{p}$ dan $\alpha$ tersebut yang artinya adalah tidak ada hubungan masa kerja dengan gangguan faal paru pekerja overhaul power plant PT. PJB Unit Pelayanan Pemeliharaan Wilayah Timur.

Hubungan status merokok dengan gangguan faal paru pekerja overhaul power plant menyatakan bahwa pekerja dengan status faal paru normal hanya terdapat pada kelompok perokok aktif $(17,39 \%)$, sedangkan pada kelompok pekerja dengan status perokok pasif dan mantan perokok diketahui tidak terdapat satupun pekerja yang memiliki faal paru normal.

Hasil analisis data dengan statistik Chi Square Test menunjukkan bahwa nilai $\chi^{2}$ hitung $=0,99$ dengan nilai $\mathrm{p}=0,71>\alpha=0,05$, maka berdasarkan perbandingan nilai $\mathrm{p}$ dan $\alpha$ tersebut jelas terlihat bahwa tidak ada hubungan status merokok dengan kejadian gangguan faal paru pekerja overhaul power plant PT. PJB Unit Pelayanan Pemeliharaan Wilayah Timur. Hubungan status gizi dengan gangguan faal paru pekerja overhaul power plant berdasarkan Tabel 3 menyatakan bahwa pekerja dengan status gizi normal sebagian besar mengalami gangguan faal paru, sedangkan pekerja dengan status gizi underweight dan obese I tak seorangpun yang memiliki status faal paru normal. Hasil analisis data dengan menggunakan statistik Chi Square Test menunjukkan $\chi^{2}$ hitung $=2,93$ dengan nilai $\mathrm{p}=0,39>\alpha=0,05$ yang artinya adalah tidak terdapat hubungan status gizi dengan gangguan faal paru pekerja overhaul power plant PT. PJBUnit Pelayanan Pemeliharaan Wilayah Timur

Berdasarkan hasil analisis karakteristik pekerja yang meliputi usia, masa kerja, status merokok, dan status gizi diketahui bahwa tidak ada hubungan antara karakteristik pekerja dengan gangguan faal paru pekerja overhaul power plant $(\mathrm{p}>\alpha)$.

\section{Hubungan Lama Paparan dengan Gangguan Faal Paru Pekerja}

Hubungan lama paparan dengan gangguan faal paru pekerja dianalisis dengan menggunakan crosstabs dan uji statistika menggunakan Chi Square Test $\left(\chi^{2}\right)$ tersaji pada Tabel 4.

Lama paparan pekerja overhaul power plant PT. PJB Unit Pelayanan Pemeliharaan Wilayah Timur terdiri dari 3 (tiga) kategori, yaitu pekerja pada kelompok lama paparan kurang dari 8 jam, 8 jam, dan lebih dari 8 jam sehari

Hasil yang tersaji pada Tabel 4 menunjukkan bahwa pekerja dengan lama paparan $<8$ jam lebih banyak yang memiliki faal paru normal dibanding 
pekerja dengan lama paparan 8 jam dan lebih dari 8 jam sehari.

Pekerja dengan lama paparan kurang dari 8 jam sehari lebih sedikit yang mengalami gangguan faal paru, sedangkan pekerja dengan lama paparan 8 jam sehari dan lebih dari 8 jam sehari ditemukan lebih banyak pekerja yang mengalami gangguan faal paru dengan persentase yang tidak berbeda jauh, yaitu $92,9 \%$ pekerja pada lama paparan 8 jam sehari dan $90 \%$ pekerja pada kelompok lama paparan lebih dari 8 jam dalam sehari.

Tabel 4. Hubungan Lama Paparan dengan Gangguan Faal Paru Pekerja Overhaul Power Plant PT. PJB Unit Pelayanan Pemeliharaan Wilayah Timur Tahun 2015

\begin{tabular}{|c|c|c|c|c|c|c|}
\hline \multirow{3}{*}{$\begin{array}{c}\text { Lama } \\
\text { Paparan }\end{array}$} & \multicolumn{4}{|c|}{ Status Faal Paru } & \multirow{2}{*}{\multicolumn{2}{|c|}{ Total }} \\
\hline & \multicolumn{2}{|c|}{ Gangguan } & \multicolumn{2}{|c|}{ Normal } & & \\
\hline & $\mathbf{n}$ & $\%$ & $\mathbf{n}$ & $\%$ & n & $\%$ \\
\hline$<8$ jam & 6 & 75,00 & 2 & 25,00 & 8 & 100 \\
\hline 8 jam & 13 & 92,86 & 1 & 7,14 & 14 & 100 \\
\hline$>8$ jam & 9 & 90,00 & 1 & 10,00 & 10 & 100 \\
\hline Total & 28 & 87,50 & 4 & 12,50 & 32 & 100 \\
\hline
\end{tabular}

Chi Square Test ( $p$ value $)=0,54$

Hasil analisis hubungan lama paparan dengan gangguan faal paru pekerja secara statistik dengan menggunakan Chi Square Test $\left(\chi^{2}\right)$ menunjukkan $\chi^{2}$ hitung $=1,63$ dengan nilai $\mathrm{p}=0,54$ menunjukkan bahwa nilai $\mathrm{p}$ lebih dari $\alpha(\mathrm{p}>\alpha=0,05)$, maka berdasarkan perbandingan nilai $\mathrm{p}$ dan $\alpha$ tersebut jelas terlihat bahwa tidak ada hubungan lama paparan dengan gangguan faal paru pekerja overhaul power plant.

\section{Hubungan Paparan Debu dengan Gangguan Faal Paru}

Analisis hubungan paparan debu dengan gangguan faal paru pekerja overhaul power plant dianalisis dengan crosstabs dan secara statistika dengan Chi Square Test. Hubungan paparan debu dengan gangguan faal paru pekerja overhaul power plant tersaji pada Tabel 5 .

Hubungan paparan kadar debu dengan gangguan faal paru pekerja overhaul power plant berdasarkan Tabel 5 menunjukkan bahwa pekerja dengan paparan kadar debu total sebesar $1,34 \mathrm{mg} / \mathrm{m}^{3}$ memiliki risiko yang lebih rendah dalam mengalami gangguan faal paru dibandingkan dengan pekerja dengan paparan kadar debu total $5,35 \mathrm{mg} / \mathrm{m}^{3}$. Pekerja overhaul power plant pada area kerja dengan paparan debu tertinggi $\left(5,35 \mathrm{mg} / \mathrm{m}^{3}\right)$ seluruhnya mengalami gangguan faal
Tabel 5. Hubungan Paparan Debu dengan Gangguan Faal Paru Pekerja Overhaul Power Plant Tahun 2015

\begin{tabular}{lcccccc}
\hline \multirow{2}{*}{$\begin{array}{c}\text { Paparan Debu } \\
\left(\mathbf{m g} / \mathbf{m}^{\mathbf{3}}\right)\end{array}$} & \multicolumn{3}{c}{ Status Faal Paru } & \multirow{2}{*}{ Total } \\
\cline { 2 - 6 } & Gangguan & \multicolumn{2}{c}{ Normal } & & \\
\cline { 2 - 6 } & $\mathbf{n}$ & $\mathbf{\%}$ & $\mathbf{n}$ & $\mathbf{\%}$ & $\mathbf{n}$ & $\mathbf{\%}$ \\
\hline 1,34 & 6 & 60,00 & 4 & 40,00 & 10 & 100 \\
5,35 & 22 & 100 & 0 & 0,00 & 22 & 100 \\
\hline Total & 28 & 87,50 & 4 & 12,50 & 32 & 100 \\
\hline Chi Square Test $(p$ value $)=0,54$ & & & \\
\hline Phi and Cramer's $V=0,56$ \\
\hline
\end{tabular}

paru $(100 \%)$ dan tidak seorang pun yang memiliki faal paru normal. Pekerja pada area kerja dengan paparan debu terendah $\left(1,34 \mathrm{mg} / \mathrm{m}^{3}\right)$ masih ada yang memiliki status faal paru normal meskipun hanya sebagian kecil $(40 \%)$.

Hasil crosstabs menunjukkan bahwa terdapat hubungan paparan debu di lingkungan kerja overhaul power plant dengan terjadinya gangguan faal paru, karena terlihat bahwa semakin tinggi paparan debu di lingkungan kerja overhaul power plant maka semakin tinggi pula persentase pekerja yang mengalami gangguan faal paru.

Hasil analisis hubungan paparan debu dengan gangguan faal paru pekerja menggunakan statistik Chi Square Test $\left(\chi^{2}\right)$ menunjukkan nilai $\chi^{2}$ hitung $=$ 6,73 dengan nilai $p=0,00$. Nilai signifikansi sebesar 0,00 yang dibandingkan dengan nilai $p$ menunjukkan bahwa nilai $\mathrm{p}$ lebih kecil dari nilai $\alpha(\mathrm{p}=0,00<\alpha$ $=0,05)$ yang artinya adalah ada hubungan paparan debu dengan gangguan faal paru pekerja overhaul power plant PT. PJB Unit Pelayanan Pemeliharaan Wilayah Timur.

Kuat hubungan yang terjadi antara paparan debu dengan gangguan faal paru pekerja overhaul power plant ditunjukkan pada koefisien $P h i$ dan Cramer's $V$ dengan nilai koefisien 0,56 yang berarti hubungan positif dan cukup kuat, sehingga dapat disimpulkan bahwa ada hubungan yang cukup kuat antara paparan debu dengan gangguan faal paru pekerja overhaul power plant PT. PJB Unit Pelayanan Pemeliharaan Wilayah Timur.

\section{PEMBAHASAN}

Pekerja overhaul power plant PT. PJB Unit Pelayanan Pemeliharaan Wilayah Timur dijadikan responden dalam penelitian ini karena pekerja berisiko tinggi terpapar debu di lingkungan kerja akibat dari proses pekerjaan overhaul. Proses pekerjaan overhaul merupakan pekerjaan 
pembersihan mesin pembangkit yang banyak menghasilkan debu sebagai efek samping yang ditimbulkan. Debu di area kerja overhaul merupakan debu yang dihasilkan dari proses pekerjaan pembersihan mesin condensate yang terbuat dari bahan tembaga.

Pekerja dengan status gangguan faal paru sebagian besar mengalami gangguan faal paru kombinasi (restriksi-obstruksi). Gangguan faal paru pekerja dipengaruhi oleh berbagai faktor, baik faktor dari lingkungan kerja maupun faktor dari diri pekerja. Faktor dari diri pekerja yang dapat mempengaruhi faal paru seperti usia, masa kerja, status merokok dan status gizi.

Menurut Suma'mur (2013), efek gangguan kesehatan karena paparan partikel sebagai bahan kimia disebabkan karena berbagai faktor, seperti sifat fisik partikel, sifat kimiawi, port of entry, dan faktor dari pekerja itu sendiri. Faktor dari pekerja itu sendiri meliputi usia, habituasi (penyesuaian diri), daya tahan tubuh (toleransi), dan derajat kesehatan tubuh.

Menurut Siswanto (1991) dalam Atmaja (2007), menyatakan bahwa pertambahan usia seseorang akan mempengaruhi jaringan tubuh. Fungsi elastisitas jaringan paru akan mengalami penurunan, sehingga kekuatan pernapasan akan melemah.

Hasil penelitian menunjukkan bahwa sebagian besar pekerja overhaul power plant berada pada usia 21-30 tahun dan seluruhnya mengalami gangguan faal paru. Pekerja overhaul power plant dengan usia lebih dari 40 tahun dengan gangguan faal paru memiliki persentase lebih besar dibandingkan pekerja dengan faal paru normal. Hal ini menunjukkan bahwa pekerja dalam berbagai kelompok usia sama-sama memiliki prevalensi tinggi terhadap terjadinya gangguan faal paru. hasil penelitian ini sejalan dengan teori Suma'mur (2013), yang menyatakan bahwa gangguan faal paru pekerja juga dipengaruhi oleh faktor dari pekerja itu sendiri, selain usia terdapat faktor lain yang mempengaruhi kondisi faal paru, seperti habituasi (penyesuaian diri), daya tahan tubuh (toleransi), dan derajat kesehatan tubuh.

Usia bukan merupakan satu-satu nya faktor dari dalam diri pekerja yang dapat mempengaruhi terjadinya gangguan faal paru pekerja overhaul power plant. Setiap pekerja memiliki daya tahan tubuh yang berbeda dan setiap pekerja memiliki kemampuan toleransi yang berbeda terhadap agent kimia yang masuk ke dalam tubuh meskipun berada pada tingkatan usia yang sama. Setiap pekerja merupakan individu yang memiliki derajat kesehatan yang berbeda. Faktor genetik juga tidak dapat lepas dari diri setiap pekerja, faktor genetik mampu menentukan kerentanan individu dan ketahanan tubuh yang berbeda meskipun dalam kelompok usia yang sama, sehingga tidak dapat dikatakan bahwa seseorang yang mengalami peningkatan usia berarti mengalami peningkatan pula pada gangguan faal paru.

Pekerja overhaul power plant dengan masa kerja 5-10 tahun dan $>10$ tahun memiliki risiko yang sama dalam mengalami gangguan faal paru, namun pekerja dengan masa kerja minimal justru lebih banyak yang mengalami gangguan faal paru. Pekerja dengan lama paparan $\leq 8 \mathrm{jam}, 8$ jam, dan $>8$ jam sama-sama memiliki kecenderungan dalam mengalami gangguan faal paru.

Pekerja overhaul power plant dengan status perokok aktif diketahui mayoritas pekerja mengalami gangguan faal paru dan hanya sebagian kecil yang memiliki kondisi faal paru normal. Hasil penelitian ini membuktikan bahwa merokok merupakan faktor risiko dalam terjadinya gangguan faal paru. Pekerja overhaul power plant dengan status perokok pasif dan mantan perokok juga memiliki risiko mengalami gangguan faal paru, hal ini sesuai dengan pernyataan Amin (1996), yang menyatakan bahwa asap rokok tidak hanya mengancam jiwa perokok itu sendiri, namun juga orang yang sehat baik anak-anak maupun dewasa. Asap rokok mampu menimbulkan gangguan kesehatan baik bagi perokok maupun bukan perokok.

Menurut Amin (1996), asap rokok dapat menimbulkan kerusakan lokal saluran pernapasan, seperti hilangnya fungsi bulu getar. Bulu getar berfungsi sebagai penghalau benda asing, sehingga benda asing dan polutan lain tidak akan mudah masuk ke dalam paru. Penurunan fungsi bulu getar ini meningkatkan risiko terjadinya gangguan faal paru, karena debu dan polutan dapat dengan mudah masuk ke dalam paru. Teori ini jelas menyatakan bahwa asap rokok mampu mengakibatkan terjadinya penurunan faal paru, sehingga gangguan faal paru tidak hanya dialami pada perokok aktif dan mantan perokok, namun dapat juga dialami oleh perokok pasif, sehingga hasil penelitian ini juga sejalan dengan hasil penelitian Damayanti dkk (2007), yang menyatakan bahwa tidak ada hubungan status merokok dengan gangguan faal paru.

Status gizi pekerja overhaul power plant dikategorikan menjadi underweight, normal, at risk obese, obese I, dan obese II. Hasil penelitian 
diketahui bahwa sebagian besar pekerja yang berstatus gizi normal mengalami gangguan faal paru, sedangkan pekerja pada kelompok status underweight seluruhnya mengalami gangguan faal paru. Hasil analisis menunjukkan bahwa tidak terdapat hubungan status gizi dengan gangguan faal paru pekerja, hal ini sejalan dengan hasil penelitian Luthfi dkk (2014), yang menyatakan bahwa tidak terdapat hubungan bermakna pada IMT pekerja dengan status gizi pekerja.

Pekerja overhaul power plant pada kelompok obesitas tingkat I (Obese I) seluruhnya mengalami gangguan faal paru, sedangkan pada kelompok pekerja berisiko obesitas (at risk obese) sebagian besar mengalami gangguan faal paru. Hasil penelitian ini sejalan dengan teori Alsagaff (2009) menyatakan bahwa obesitas merupakan suatu masalah kesehatan, karena salah satu dampak obesitas adalah mengganggu kesehatan pernapasan. Seseorang dengan obesitas memiliki risiko tinggi mengalami gangguan faal paru, karena otot pernapasan pada orang obesitas harus bekerja lebih keras dibandingkan kerja otot pada orang normal.

Faktor lama paparan dalam sehari merupakan salah satu faktor risiko dalam terjadinya gangguan faal paru pekerja. Suma'mur (2013), menyatakan bahwa semakin lama masa kerja seseorang, maka semakin tinggi pula tingkat risiko dalam terjadinya gangguan faal paru.

Hubungan lama paparan dengan gangguan faal paru pekerja overhaul ditunjukkan pada Tabel 4 yang menunjukkan bahwa pekerja dengan lama paparan 8 jam sehari dan $>8$ jam sehari diketahui lebih dari $90 \%$ pekerja mengalami gangguan faal paru. Pekerja dengan status faal paru normal lebih banyak dijumpai pada kelompok lama paparan $<8$ jam sehari dibandingkan kelompok pekerja dengan lama paparan $\geq 8$ jam sehari. Pekerja dengan lama paparan $\leq 8$ jam, 8 jam, dan $>8$ jam sama-sama memiliki risiko tinggi dalam mengalami gangguan faal paru.

Hasil penelitian pada Tabel 4 menunjukkan bahwa tidak terdapat hubungan lama paparan dengan gangguan faal paru pekerja overhaul power plant. Penelitian ini jelas tidak sejalan dengan teori yang ada, Suma'mur (2013), menyatakan bahwa semakin lama waktu kerja seseorang, maka semakin tinggi pula tingkat risiko dalam terjadinya gangguan faal paru. Selain itu, Suma'mur (2013), juga menyatakan bahwa masa kerja menentukan lama paparan seseorang terhadap faktor risiko terpapar debu, sehingga semakin besar lama paparan seseorang maka semakin besar pula risiko terkena penyakit paru.

Hasil penelitian ini tidak dapat membuktikan adanya keterkaitan hubungan antara lama paparan dengan kejadian gangguan faal paru, karena gangguan faal paru yang terjadi pada pekerja overhaul power plant bukan merupakan efek pemajanan akut. Gangguan faal paru yang terjadi bukan semata-mata disebabkan karena pekerja terpapar debu dalam waktu yang kurang dari 8 jam per hari atau bahkan lebih dari 8 jam per hari. Hasil penelitian ini sejalan dengan hasil penelitian Mengkidi (2006), yang menyatakan bahwa tidak ada hubungan antara lama paparan dengan gangguan faal paru pekerja.

Hasil penelitian ini tidak dapat membuktikan adanya keterkaitan hubungan antara lama paparan dengan terjadinya gangguan faal paru pekerja, karena gangguan faal paru yang terjadi pada pekerja overhaul power plant bukan merupakan efek pemajanan akut. Gangguan faal paru yang terjadi merupakan efek dari pemajanan kronis.

Gangguan faal paru yang terjadi bukan sematamata disebabkan karena pekerja terpapar debu dalam waktu yang kurang dari 8 jam perhari atau bahkan lebih dari 8 jam per hari. Hasil penelitian ini sejalan dengan teori Soeripto (2008), menyatakan bahwa salah satu faktor yang mempengaruhi terjadinya gangguan faal paru pada pekerja yang terpapar debu adalah lama pemajanan. Efek gangguan kesehatan yang ditimbulkan dapat terjadi dalam jangka waktu tertentu, sehingga lama paparan dalam sehari belum dapat digunakan sebagai indikator untuk menentukan gangguan kesehatan.

Menurut Soeripto (2008), gangguan faal paru merupakan efek dari pemajanan kronis, sehingga pengaruhnya dapat diketahui dalam waktu relatif lama. Hal ini menjelaskan bahwa penyebab gangguan faal paru tidak dapat dilihat hanya dari lama paparan sehari atau waktu pemajanan singkat, namun membutuhkan waktu yang relatif lama. Hal ini sejalan dengan hasil penelitian yang tersaji pada Tabel 4 yang menyatakan bahwa tidak terdapat hubungan lama paparan dengan gangguan faal paru pekerja.

Faktor lain yang diduga kuat memiliki hubungan dengan terjadinya gangguan faal paru pekerja adalah debu. Debu di lingkungan kerja diduga sebagai faktor potensial dalam menimbulkan gangguan faal paru pekerja. Dugaan ini didukung dengan tinjauan teoritis yang disampaikan Amin (1996), bahwa debu merupakan faktor risiko yang sangat kuat untuk 
menimbulkan gangguan faal paru dan penyakit pernapasan seperti bronkitis kronis hingga asma. Menurut Danusantoso (2000), semua jenis debu berpotensi menyebabkan timbulnya bronkitis kronis, semakin kecil ukuran debu, maka dapat memberikan efek yang semakin berbahaya bagi kesehatan paru.

Hasil pengukuran debu di dua titik (Tabel 2) menunjukkan bahwa kadar debu di lingkungan kerja overhaul power plant sebesar $1,34 \mathrm{mg} / \mathrm{m}^{3}$ dan $5,35 \mathrm{mg} / \mathrm{m}^{3}$. Debu di lingkungan kerja overhaul power plant berasal dari pekerjaan overhaul power plant, salah satu pekerjaan yang menghasilkan debu adalah pekerjaan pembersihan condensate dan pembersihan material mesin pembangkit lainnya.

Menurut Soedomo (1999) dalam Yulaekah (2007), debu sebagai agent pencemar udara mampu menyebabkan penyakit pernapasan kronis seperti bronkitis kronis, efisema paru, asma bronkiale bahkan kanker paru. Yulaekah (2007), menyatakan bahwa kelainan paru karena adanya deposit debu dalam jaringan paru disebut pneumoconiosis.

Hasil analisis hubungan paparan debu dengan gangguan faal paru yang tersaji pada Tabel 5 menunjukkan bahwa pekerja overhaul power plant yang terpapar kadar debu $1,34 \mathrm{mg} / \mathrm{m}^{3}$ terdapat mayoritas pekerja mengalami gangguan faal paru dan hanya sebagian kecil pekerja dengan faal paru normal, sedangkan pekerja di area paparan debu $5,35 \mathrm{mg} / \mathrm{m}^{3}$ ditemukan seluruh pekerja mengalami gangguan faal paru. Pada lingkungan kerja overhaul power plant dengan paparan debu $5,35 \mathrm{mg} / \mathrm{m}^{3}$ diketahui tidak ada satu pun pekerja yang memiliki status faal paru normal. Hasil analisis diatas terlihat bahwa terdapat hubungan paparan debu dengan gangguan faal paru pekerja. Hasil statistik Chi Square Test pada Tabel 5 membuktikan bahwa terdapat hubungan bermakna antara paparan debu dengan terjadinya gangguan faal paru pekerja overhaul power plant. Kuat hubungan yang terjadi menunjukkan angka koefisien 0,56 yang berarti terdapat hubungan yang cukup kuat antara paparan debu dengan terjadinya gangguan faal paru pekerja.

Hasil penelitian ini sejalan dengan teori yang Suma'mur (2013) dan Soeripto (2008). Menurut Suma'mur (2013), debu merupakan agent kimia yang dalam keadaan tertentu dapat menyebabkan pengurangan kenyamanan kerja, gangguan penglihatan, gangguan faal paru, bahkan menimbulkan keracunan umum. Soeripto (2008) menyatakan bahwa debu termasuk bahan partikel toksikan yang dapat diabsorbsi paru. Debu terhirup dan masuk ke dalam tubuh secara inhalasi, proses penimbunan debu hingga menyebabkan gangguan faal paru dipengaruhi oleh jenis partikel, lama pajanan, besarnya kadar partikel, dan ukuran partikel debu.

Hasil penelitian ini sejalan dengan hasil penelitian Cahyana (2012), yang menyatakan bahwa paparan kadar debu di tempat kerja memiliki hubungan dengan kejadian gangguan faal paru. Hasil ini didukung dengan hasil penelitian Yulaekah (2007), yang menunjukkan bahwa ada hubungan yang bermakna antara paparan debu dengan gangguan faal paru, sehingga dapat dikatakan bahwa kadar debu di lingkungan kerja merupakan faktor risiko terjadinya gangguan faal paru dengan nilai Odds Ratio (OR) 5,127 yang artinya pekerja terpapar debu memiliki risiko mengalami gangguan faal paru 5 kali lebih besar dibandingkan pekerja yang tidak terpapar debu.

Hasil analisis yang tersaji pada Tabel 5 juga menunjukkan bahwa semakin tinggi paparan debu di lingkungan kerja overhaul power plant, maka risiko terjadinya gangguan faal paru pekerja juga semakin tinggi. Hal ini sesuai dengan teori yang disampaikan Soeripto (2008), bahwa kadar partikel di udara merupakan salah satu faktor yang mempengaruhi terjadinya gangguan faal paru pekerja. Suma'mur (2013), juga menyatakan bahwa konsentrasi kadar partikel di udara merupakan salah satu faktor yang mempengaruhi tingkat keparahan yang ditimbulkan, sehingga semakin tinggi paparan debu di udara, maka semakin tinggi pula risiko gangguan faal paru.

Debu yang ada di lingkungan kerja overhaul power plant dapat masuk ke dalam tubuh pekerja secara inhalasi hingga menyebabkan gangguan faal paru. Ukuran debu menentukan di mana lokasi debu terdeposit, semakin kecil ukuran debu semakin tinggi tingkat keparahan yang ditimbulkan. Debu yang terukur di lantai 1 dan lantai 2 lingkungan pekerjaan overhaul masih tergolong di bawah NAB, namun meskipun demikian mayoritas pekerja overhaul mengalami gangguan faal paru. Hal ini dikarenakan debu di lingkungan kerja overhaul kemungkinan besar mengandung debu tembaga akibat dari proses pembersihan mesin condensate. Mesin condensate merupakan salah satu mesin pembangkit listrik yang terbuat dari tembaga, sehingga debu yang ada di udara lingkungan overhaul power plant memiliki kemungkinan besar mengandung tembaga

Debu tembaga memberikan efek pajanan yang lebih besar dibandingkan debu biasa. Debu 
tembaga $(\mathrm{Cu})$ memiliki sifat tidak dalam larut air, bersifat sitogenik, genetogenik, dan berwarna coklat kemerahan (reduce brown), sehingga debu tembaga ini dapat menyebabkan gangguan ginjal, hati, syaraf, dan saluran pencernaan seperti mual, muntah, diare, selain itu debu tembaga mampu menyebabkan kulit dan rambut berubah warna menjadi coklatkemerahan seperti warna tembaga yang disebut dengan discoloration of hair and skin. Efek umum yang ditimbulkan dari debu tembaga adalah terjadinya demam akibat paparan debu tembaga yang disebut dengan Metal Fume Fever karena debu tembaga ini sangat toksik dalam menyebabkan gangguan kesehatan.

American Conference of Governmental Industrial Hygienists (ACGIH) Guideline menyatakan bahwa TLV-TWA batas kontaminan untuk debu tembaga sebesar $0,1 \mathrm{mg} / \mathrm{m}^{3}$ yang dapat diterima oleh pekerja tanpa mengakibatkan penyakit atau gangguan kesehatan selama melakukan pekerjaan sehari-hari untuk waktu yang tidak melebihi 8 jam sehari atau 40 jam seminggu. Jadi meskipun debu terukur di lingkungan kerja overhaul masih tergolong di bawah NAB, namun banyak ditemukan pekerja dengan gangguan faal paru. Hal ini dikarenakan debu di lingkungan kerja mengandung debu tembaga $(\mathrm{Cu})$ yang memberikan efek toksik bagi kesehatan pernapasan pekerja. Penyebab lain yang mendukung terjadinya gangguan faal paru pekerja overhaul power plant karena adanya beberapa pekerja yang mengalami lama paparan lebih dari 8 jam sehari.

\section{SIMPULAN}

Berdasarkan hasil analisis penelitian dapat disimpulkan bahwa pekerja overhaul power plant mayoritas berusia 21-30 tahun dengan masa kerja 5-10 tahun, lama paparan 8 jam sehari, berstatus perokok aktif, dan berstatus gizi normal. Paparan kadar debu lingkungan kerja overhaul power plant terukur masih di bawah Nilai Ambang Batas (NAB) yang berlaku.

Status faal paru pekerja overhaul power plant diketahui terdapat $12,50 \%$ pekerja memiliki faal paru normal dan $87,50 \%$ pekerja mengalami gangguan faal paru dengan gangguan faal paru pekerja overhaul power plant terdiri dari gangguan restriksi dan kombinasi dengan mayoritas pekerja mengalami gangguan kombinasi.

Karakteristik pekerja overhaul power plant yang meliputi usia, masa kerja, status merokok, dan status gizi terbukti secara statistik tidak terdapat hubungan dengan gangguan faal paru. Analisis hubungan secara statistik menunjukkan bahwa tidak terdapat hubungan lama paparan dengan gangguan faal paru pekerja overhaul power plant $(\mathrm{p}>0,05)$, sedangkan terdapat hubungan signifikan antara paparan debu dengan gangguan faal paru pekerja overhaul power plant $(\mathrm{p}=0,00<0,05)$.

Keterbatasan dalam penelitian ini adalah tidak diperolehnya data status faal paru pekerja pada saat pertama kali diterima bekerja di PT. PJB Unit Pelayanan Pemeliharaan Wilayah Timur. Saran untuk penelitian selanjutnya adalah data pemeriksaan kesehatan awal perlu diperoleh peneliti selanjutnya untuk memastikan bahwa gangguan faal paru yang terjadi benar-benar disebabkan karena lingkungan pekerjaan overhaul bukan karena pekerjaan sebelumnya.

\section{DAFTAR PUSTAKA}

Alsagaff. 2009. Dasar-dasar Ilmu Penyakit Paru. Surabaya: Airlangga University Press.

Amin. M. 1996. Penyakit Paru Obstruktif Menahun: Polusi Udara, Rokok, dan Alfa-1-antitripsin. Surabaya: Airlangga University Press.

Ardam, Kiky Aunillah Yolanda. 2015. Analisis Hubungan Paparan Debu dengan Gangguan Faal Paru Pekerja Overhaul Power Plant. Skripsi. Surabaya. Universitas Airlangga.

Atmaja, Aditya S. dan Denny, Ardyanto. 2007. Identifikasi Kadar Debu di Lingkungan Kerja dengan Keluhan Subyektif Pernapasan Tenaga Kerja Bagian Finish Mill. Jurnal Kesehatan Lingkungan, Vol. 3, No. 2, hal. 161-172.

Damayanti, Tria. Faisal, Yunus., Mukhtar, Ikhsan., dan Kiki, Sutjahyo. 2007. Hubungan Penggunaan Masker dengan Gambaran Klinis, Faal Paru dan Foto Toraks Pekerja Terpajan Debu. Majalah Kedokteran Indonesia, Vol. 7, No. 9, hal. 289-299.

Danusantoso, Halim. 2000. Buku Saku Ilmu Penyakit Paru. Jakarta: Hipokrates.

International Labour Organization. 2005. Data ILO tentang Kasus Penyakit Akibat Kerja (PAK) Dunia.

Kementerian Tenaga Kerja dan Transmigrasi. 2011. PERMEN 13/MEN/X/2011 tentang Nilai Ambang Batas Faktor Fisika dan Kimia di Tempat Kerja. Jakarta.

Kusuma, Haifa Nabila. 2013. Risk Assassment pada Pekerjaan Overhaul Pembersihan Boiler Bagian 
Furnance di PT PJB Gresik. Skripsi. Surabaya. Universitas Airlangga.

Luthfi, Amir. Yunus, Faisal., Prasenohadi., dan Prihartono, Joedo. 2014. Faktor-faktor yang Mempengaruhi Faal Paru Polisi Lalu Lintas di Wilayah Jakarta Timur. Jurnal Respir Indo, Vol 34, No. 1, hal. 87-94.

Mengkidi, Dorce. 2006. Gangguan Fungsi Paru dan Faktor-faktor yang Mempengaruhi pada Karyawan PT Semen Tonasa Pangkep Sulawesi Selatan. Tesis. Semarang. Universitas Diponegoro.

Mukono, H.J. 2005. Toksikologi Lingkungan.

Surabaya: Airlangga University Press.
Perdana, Anugrah. Djajakusli, Rafaael., Syafar, Muhammad.2010. Faktor Risiko Paparan Debu pada Faal Paru Pekerja Bagian Produksi PT. Semen Tonasa Pangkep 2009. Jurnal MKMI, Vol 6, No. 3, hal. 160-167.

Soeripto, M. 2008. Higiene Industri. Jakarta: Balai Penerbit Fakultas Kedokteran Universitas Indonesia.

Suma'mur, P.K. 2013. Higiene Perusahaan dan Kesehatan Kerja (HIPERKES). Jakarta: Agung Seto.

Yulaekah, Siti. 2007. Paparan Debu Terhirup dan Gangguan Fungsi Paru pada Pekerja Industri Batu Kapur. Tesis. Semarang. Universitas Diponegoro. 